\title{
Dutch Printed Private Library Sales Catalogues, 1599-18oo: A Bibliometric Overview
}

\author{
RindertJagersma
}

As historical sources, early modern printed private library sales catalogues can be used to study the book trade, book ownership, and readership. ${ }^{1}$ Just as other historical documents, these sources should be handled with care and the researcher should be aware of the pitfalls. ${ }^{2}$ For example, a book owned is not necessary a book read, and the other way around. Furthermore, a catalogue represents a library only at a specific time (mostly after the death of the collector). Before a sale, books could have been taken out of the collection by heirs, or books could be added by a bookseller who wanted to get rid of unsold stock. The purpose of a catalogue was not to register a private library or a collection as accurate and detailed as possible, but to sell the profitable books for as much profit as possible. An overly detailed description would cost additional

1 Daniel Mornet, 'Les Enseignements des Bibliothèques Privées (1750-1780)', Revue d'Histoire Littéraire de La France, 17 (1910), pp. 449-496; S.A. Krijn, 'Franse lektuur in Nederland in het begin van de 18e eeuw', De Nieuwe Taalgids, XI (1917), pp. 161-178; Bert van Selm, Een menighte treffelijcke boecken: Nederlandse boekhandelscatalogi in het begin van de zeventiende eeuw (Utrecht: HES, 1987); Alicia C. Montoya, 'French and English Women Writers in Dutch Library Catalogues, 1700-180o. Some Methodological Considerations and Preliminary Results', in Suzan van Dijk (ed.), 'I Have Heard about You'. Foreign Women's Writing Crossing the Dutch Border: From Sappho to Selma Lagerlöf (Hilversum: Verloren, 2004), pp. 182-216; Alicia C. Montoya and Rindert Jagersma, 'Marketing Maria Sibylla Merian, 1720-180o: Book Auctions, Gender, and Reading Culture in the Dutch Republic', Book History, 21 (2018), pp. 56-88. This project has received funding from the European Research Council (ERC) under the European Union's Horizon 2020 research and innovation program under grant agreement No. 682022. The author would like to thank Tamara Bouwman for her helpful advice, and the reviewers and the participants of the 'Book Trade Catalogues in Early Modern Europe' workshop for their comments on the draft of this paper.

2 For the question to what extent and in which capacity printed catalogues of private libraries can be used as a source for the history of reading and the main pitfalls of this source: Helwi Blom, Rindert Jagersma and Juliette Reboul, 'Printed Private Library Catalogues as a Source for the History of Reading', in Mary Hammond (ed.), Edinburgh History of Reading. Early Readers (Edinburgh: Edinburgh University Press, 2020), pp. 249-269. 
labour and would make the catalogue more extensive and thus more expensive to produce. ${ }^{3}$

Using printed private library catalogues as a historical source provides insight into book ownership in the Dutch Republic in the period 1599-180o. It is important to state that the content of the printed private library catalogues does not represent the average book collection of a Dutch household or library. Handwritten probate inventories show that most families had only a couple of (mainly religious) books - Bibles, catechisms, psalms, and sermons. Those books were accompanied by works that contained practical information, like almanacs. ${ }^{4}$ Researchers should thus be aware that the printed book sales catalogues of private libraries only show us the books and collections considered worth auctioning. ${ }^{5}$

Besides this, one should be conscious that the preserved copies are not representative of the actual auctions held. We therefore have to establish how many, and especially which, Dutch book sales catalogues have survived the test of time. After all, catalogues are ephemeral material. ${ }^{6}$ It is necessary to create a typology of preserved Dutch book sales catalogues to gain more insight into the phenomenon of catalogues and by doing so, lessen the bias on this topic. In the present study, data from the project 'Book Sales Catalogues of the Dutch Republic, 1599-1800' - a project conceived and started by Bert van Selm - is used to create this typology of printed private library catalogues. ${ }^{7}$

3 Depending on the print run, the use of one extra quire (sheet of paper) could cost between $f_{10}$ (50o copies) and $f_{20}(1,000$ copies) (around 1700 , cautious estimate). This was a considerable amount at a time when the average labourer earned one gulden per day.

4 Henk de Kooker and Bert van Selm, Boekcultuur in de Lage Landen, 1500-180o: bibliografie van publikaties over particulier boekenbezit in Noord- en Zuid-Nederland, verschenen voor 1991 (Utrecht: HES, 1993); C. Gijzen, Boekbezit in Boedelinventarissen: mogelijkheden en onmogelijkheden van onderzoek naar zeventiende eeuws boekbezit in notariële archieven (Leiden: s.n., 1993); K.M.P. Strengers-Olde Kalter, 'Boeken in Bossche boedels. De belangstelling voor lectuur in de achttiende eeuw', Noordbrabants Historisch Jaarboek, 14 (1998), pp. 143-179; José de Kruif, Liefhebbers en gewoontelezers: leescultuur in Den Haag in de achttiende eeuw (Zutphen: Walburg Pers, 1999); Ruud Lambour, 'Het boekenbezit van Amsterdamse Doopsgezinden uit de Gouden Eeuw', Doopsgezinde Bijdragen Nieuwe Reeks, 40 (2014), pp. 135-160.

5 Collections of pamphlets and other ephemeral printed matter were often left out or were mentioned in packages.

6 Here a law of book history applies: the higher the print run, the smaller the chance that something has been preserved. After all, the printed catalogue was useless after the auction had ended. (Although some people used and collected them for their bibliographical information as instrument of reference.)

7 J.A. Gruys and Henk W. de Kooker, Book Sales Catalogues of the Dutch Republic, 1599-180o. Guide (Leiden: IDC Publishers, 1997). This was based on the catalogues gathered in more than fifty contributing libraries and archives. Digital copies of the catalogues and the 
More than thirty years ago, Van Selm published Een Menighte Treffelijcke Boecken (1987), his dissertation on Dutch book trade catalogues at the beginning of the seventeenth century. ${ }^{8}$ In this book, Van Selm published studies relating to the thirty-one earliest Dutch auction catalogues published in the period $1599-1611 .{ }^{9}$ This enabled him to outline the rise of the printed book auction catalogue, an innovation that he considered 'an important event in the history of the book trade..10 The aim of his study of Early Dutch book auction catalogues as historical documents was to describe the characteristics of the oldest printed auction catalogues and determine their value for book history research in general and private book ownership in particular."1 It was an exploratory study since little was known about the nature and development of the auction catalogue as a historical document. ${ }^{12}$ However, the corpus he used was small, and Van Selm emphasised that his choice to stop at the year 1611 was 'relatively arbitrary'. ${ }^{3}$ He immediately admitted: 'Hopefully in the near future it will be possible to track down and register the later published catalogues. ${ }^{14}$ With his work, Van Selm laid the foundation for an international inventory under the name 'Book Sales Catalogues of the Dutch Republic, 1599-1800' (BSC)..$^{15}$ Based on this inventory and accompanying metadata, the

metadata are currently hosted by Brill: http://primarysources.brillonline.com/browse/ book-sales-catalogues-online. See note 15 .

8 Van Selm, Een menighte.

9 Ibid., pp. 6, 152-163.

10 Ibid., p. 9. Translations of the originally Dutch quotes by the author.

11 Ibid., pp. 75-144, 76 .

12 Ibid., pp. 3, 75 .

13 In the context of his research Van Selm had to choose a certain period of time and he opted for the earliest timeframe: 1599-1611. Van Selm, Een menighte, p. 145.

14 Van Selm, Een menighte, p. 145. A large inventory of Dutch bookshop catalogues was started by Wytze Hellinga and came to be known under the name 'Apparaat Hellinga'.

15 Ibid., Een menighte, p. 145. After Van Selm passed away, the project 'Book Sales Catalogues of the Dutch Republic, 1599-180o', was executed by his collaborators; H.W. de Kooker, E. Hofland and J.A. Gruys. Together with other researchers like O.S. Lankhorst, they traced unknown copies and had them filmed on microfiches. Gruys and De Kooker noted that: 'In the past book sales catalogues have scarcely been used for historical research because of their inaccessibility'. They elucidated this by saying 'that of the roughly 1,760 items printed before 1701, only 200 (11.4\%) are to be found in Dutch libraries'. Most of the book trade catalogues are unique copies and can be found worldwide. In 2015, this collection of 3,75 o digital facsimiles was digitised by publisher Brill and placed online together with the collected metadata as 'Book Sales Catalogues Online' (BSCO). Gruys and De Kooker, Guide. Book Sales Catalogues of the Dutch Republic, pp. III-IV; O.S. Lankhorst, 'Vijftien pakketten catalogi teruggevonden. Nederlandse boekhandelscatalogi in Sint Petersburg', De Boekenwereld, 9 (1992), pp. 66-76; O.S. Lankhorst, 'Les ventes de livres en Hollande et leurs catalogues (XVII ${ }^{\mathrm{e}}$ et XVIII ${ }^{\mathrm{e}}$ Siècles)', in Annie Charron and Elisabeth Parinet 
characteristics of the Dutch printed private library sales catalogues in the period 1599-180o will be examined in this study.

The aim of this bibliometric study is to look beyond the rise (1599-1610) of the Dutch catalogue initiated by Van Selm. ${ }^{16}$ The available BSC data on 4,756 catalogues allows for a large-scale study of the development of the book sales catalogue to the year $1800 .{ }^{17}$ The data provides information about the catalogues, collectors, and auctions, which can offer insight in book collecting, readership, and the second-hand book market. By analysing the database, we can explore the size of catalogues, collectors, and the locations of the auctioned collections. This allows us to gain insight into the phenomenon of the Dutch printed book sales catalogue, and more specifically the 'private library sales catalogue', in the seventeenth and eighteenth century.

In the first section of this study, the data of the available (preserved) editions of catalogues is divided by decade and the places of origin. In the second section, an overview is given of how the survived catalogues relate to the actual book auctions. The number of auctions will be compared to the number of preserved catalogues. In the third section, the surviving editions will be investigated based on the size of the catalogues. What can we say about the larger and smaller collections of the former owners?

(eds.), Les Ventes de Livres et Leurs Catalogues XVII ${ }^{e}-X X^{e}$ Siècle (Paris: Ecole des Chartes, 2000), pp. 11-26; O.S. Lankhorst, 'Les ventes aux enchères des livres à La Haye dans la première moitié du $18^{\mathrm{e}}$ siècle', in C. Berkvens-Stevelinck (ed.), Le magasin de l'univers. The Dutch Republic as the Centre of the European Book Trade (Leiden: Brill, 1992), pp. 199210; O.S. Lankhorst, 'Dutch Book Auctions in the Seventeenth and Eighteenth centuries', in Robin Myers and Michael Harris (eds.), Under the Hammer: Book Auctions since the Seventeenth Century (New Castle, DE: Oak Knoll Press, 2001), pp. 65-88;J.A. Gruys, 'Rijklof Michael van Goens. Het mysterie van de 24.200 verdwenen catalogi', in Ton Croiset van Uchelen and Hannie van Goinga (eds.), Van pen tot laser: 31 opstellen over boek en schrift (Amsterdam: De Buitenkant, 1996), pp. 150-156, p. 152; Berry Dongelmans, 'Book Sale Catalogues in the Dutch Republic, 1599-180o', in Lotte Hellinga (ed.), The Bookshop of the World: The Role of the Low Countries in the Book-Trade, 1473-1941 ('t Goy-Houten: Hes and De Graaf, 2001), pp. 263-276.

16 Van Selm also looked at the content of the early auction catalogues, such as the order of auctioning and the classification of the books. In this study no attention will be paid to this. Van Selm, Een menighte, pp. 76, 82-92.

17 When I mention 'catalogue', I aim for a preserved edition according to the BSC database, not a single copy, unless it is explicitly mentioned. Data collected in November 2016. Data processed with SPSS 21.0.o.o. 


\section{Corpus}

When Van Selm started to collect all the known copies of book sales catalogues in a database, he included auction catalogues of (anonymous) private libraries and collections, auction catalogues of book printers and booksellers, retail stock, and wholesale stock catalogues. ${ }^{18}$ Most of the 4,756 records $(2,536$ or $53.3 \%$ ) fall into the category 'auction catalogue private library'. Together with the 686 anonymous collections they represent $67.7 \%$ of the total $(3,222)$. This results in the following subdivision of the categories of book trade catalogues (Table 4.1):

TABLE 4.1 Main categories of book sales catalogues in the BSC database

\begin{tabular}{lrc}
\hline Category & Count & Percentage \\
\hline auction catalogue private library & 2,536 & $53.3 \%$ \\
auction catalogue anonymous collection & 686 & $14.4 \%$ \\
(auction) catalogue retail or wholesale stock & 1,243 & $26.1 \%$ \\
Other & 291 & $6.1 \%$ \\
Total & 4,756 & \\
\hline
\end{tabular}

This study focuses on the printed private library sales catalogues, whether the name of the collector is printed on the title-page, or whether it was sold anonymously. Combined, both categories - henceforward private library catalogues - contain 3,222 editions. In principle, these are all known copies of private library catalogues - from the famous first known catalogue of Philips van Marnix van Sint Aldegonde (1540-1598) published in 1599, until the auction of the library of Johannes Hiddinga on 25 November $1799 .{ }^{19}$ Collections of over fifty European institutions have been searched to establish this census. Beyond doubt, new copies will be discovered in other collections in the future. ${ }^{20}$

18 Gruys, 'Rijklof Michael van Goens', p. 151.

19 The BSC also contain some catalogues published after 1800 and catalogue of which the year of publication is uncertain. Auctions were held before 1599, perhaps including printed catalogues, but the 1599 catalogue is still regarded as the oldest (surviving) catalogue of the Northern Netherlands (and the only one from the sixteenth century). Lankhorst, 'Dutch Book Auctions', p. 65.

20 Karel Bostoen and Henk de Kooker, 'Nederlandse boekhandelscatalogi uit het bezit van de Hongaarse adellijke familie Teleki', Acta Neerlandica. Bijdragen tot de Neerlandistiek Debrecen, 2 (2002), pp. 101-25. 
The preserved catalogues are not evenly distributed over time. When we group the preserved catalogues (private library catalogues as well as the retail or wholesale stock catalogues) by decade, we see the following distribution (Table 4.2):

TABLE 4.2 Number of editions of auction catalogues, sorted by decade (159os-179os)

Year

$\begin{array}{lll}\text { (Auction) catalogue } & \text { Auction catalogue } & \text { Auction catalogue } \\ \text { retail or wholesale stock } & \text { anonymous collection } & \text { private library }\end{array}$

\begin{tabular}{lrrr}
\hline 159 os & O & 0 & 1 \\
16 oos & 11 & 2 & 19 \\
161 os & 3 & 3 & 22 \\
162 os & 6 & 6 & 30 \\
163 os & 19 & 21 & 55 \\
164 os & 38 & 36 & 71 \\
165 os & 32 & 25 & 59 \\
166 os & 63 & 64 & 130 \\
167 os & 49 & 145 & 200 \\
168 os & 37 & 72 & 158 \\
169 os & 79 & 62 & 249 \\
17 os & 74 & 19 & 150 \\
171 os & 73 & 18 & 113 \\
172 os & 49 & 12 & 112 \\
173 os & 99 & 27 & 108 \\
174 os & 141 & 20 & 141 \\
175 os & 90 & 25 & 147 \\
176 os & 82 & 19 & 192 \\
177 os & 85 & 21 & 187 \\
178 os & 75 & 38 & 181 \\
179 os & 64 & 39 & 178 \\
Total & 1,169 & 674 & 2,53 \\
\hline
\end{tabular}

When we visualize this distribution, the graphs (Figure 4.1 and 4.2) clearly show that the private library catalogues (auction catalogue private library and the auction catalogue anonymous collection) form a large group $(3,177)$ compared to the retail or wholesale catalogues. ${ }^{21}$

21 In the period 1599-1799. Without some catalogues from after 1799, and without a specific year ('17uu'). Missing years: '(auction) catalogue retail stock or wholesale stock auction': 74; 'catalogue anonymous collection': 12; 'auction catalogue private library': 33. 


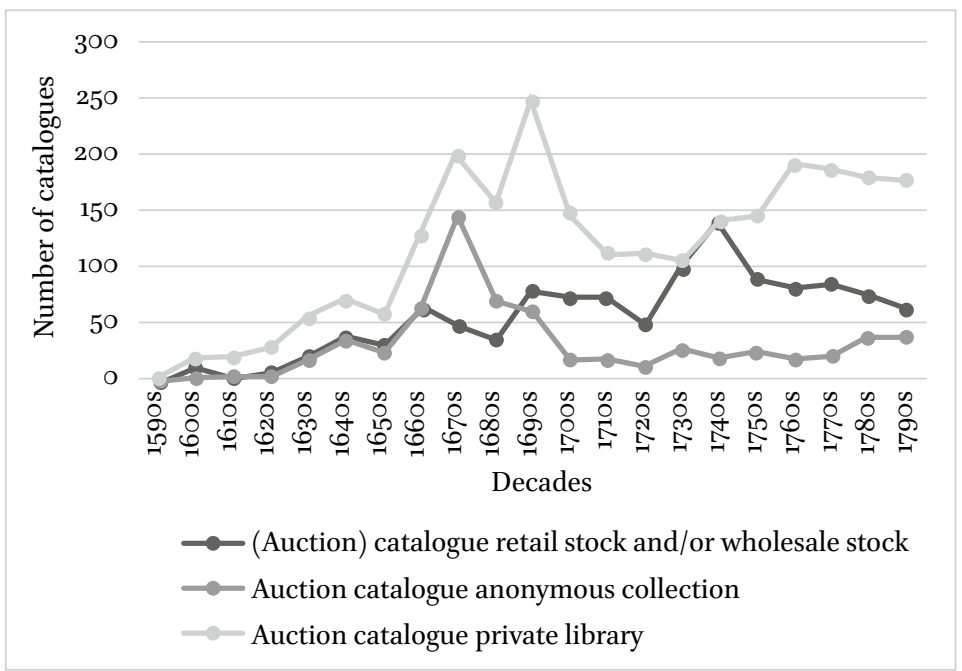

FIGURE 4.1 The number of editions of auction catalogues, sorted by decade (159os-179os) (absolute)

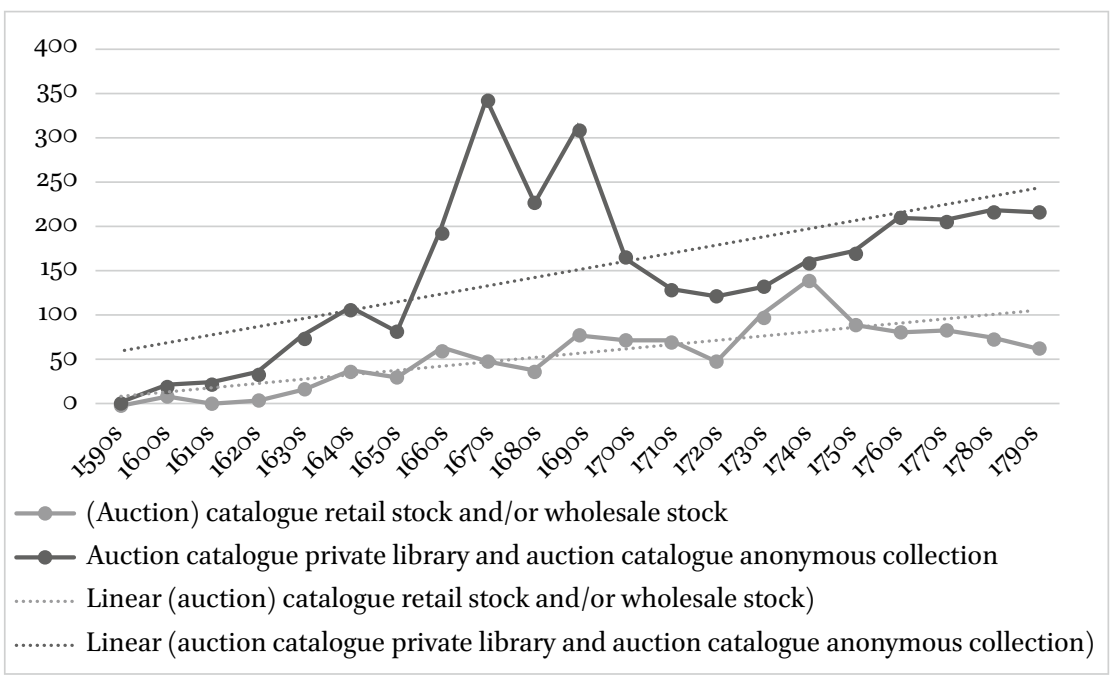

FIGURE 4.2 Private library catalogues and the retail or wholesale stock catalogues, sorted by decade (159os-179os), including trend line (absolute) 


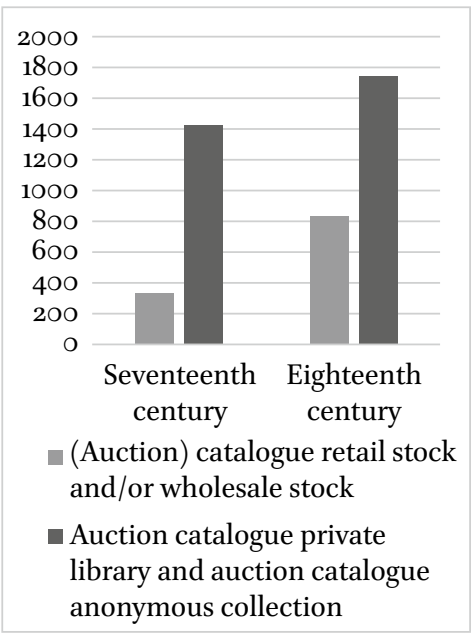

FIGURE 4.3

Private library catalogues and the retail and/ or wholesale stock catalogues, sorted by century (absolute)

Broken down into two centuries, we see that the private library catalogues are by far the largest group. For both groups the numbers increase in the eighteenth century, as Figure 4.3 shows. Looking at the two centuries, we see that $45 \%(1,429)$ of the private library catalogues come from the seventeenth century, compared to $55 \%(1,747)$ in the eighteenth century. For the retail or wholesale stock catalogue however, this is $28.8 \%$ (337) compared to $71.2 \%\left(83^{2}\right)$.

Based on this data, we can conclude that catalogues from the period $1660-$ 1699 are particularly well preserved. Some peaks could be explained by the way catalogues are preserved in collections as collected by contemporary owners. For example, the peak in the 1640 s is the result of the collection of the student Peder Laridsen Scavenius who studied in Leiden in 1643-1646. He visited a lot of auctions and kept the accompanying catalogues. In 1655, he donated those to the Royal Library of Copenhagen. Thanks to two collections in the Herzog August Bibliothek in Wolfenbüttel, we have a lot of Dutch catalogues from the periods 166o-1678 and $1685^{-1700 . ~ T h i s ~ s e c o n d ~ c o l l e c t i o n, ~ c o n s i s t i n g ~ o f ~ a r o u n d ~}$ 300 catalogues, was bought at the auction of the library of Joan Huydekooper in $1704 .^{22}$

22 Gruys, 'Rijklof Michael van Goens', p. 155; Lankhorst, 'Vijftien pakketten'; Lankhorst, 'Les Ventes de Livres'; Marika Keblusek, 'Gekocht in Den Haag. Hertog August van Wolfenbüttel en de Haagse Elzeviers', in B.P.M. Dongelmans, P.G. Hoftijzer, and O.S. Lankhorst (eds.), Boekverkopers van Europa: het 17 de-eeuwse Nederlandse uitgevershuis Elzevier (Zutphen: Walburg Pers, 2000), pp. 221-224. 
A large proportion of these auctions were held in Amsterdam, Leiden, and The Hague though not necessarily evenly distributed between these three places (Table 4.3). ${ }^{23}$

TABLE 4.3 Private library catalogues sorted by city (16oos-179os)

\begin{tabular}{lllll}
\hline Year & $\begin{array}{l}\text { Total private } \\
\text { library catalogues }\end{array}$ & Amsterdam & Leiden & The Hague
\end{tabular}

\begin{tabular}{lrrrr}
\hline 16 oos & 21 & 0 & 16 & 2 \\
161 os & 25 & 0 & 24 & 0 \\
162 os & 36 & 2 & 15 & 7 \\
163 os & 76 & 4 & 32 & 17 \\
164 os & 107 & 4 & 63 & 20 \\
165 os & 84 & 9 & 33 & 21 \\
166 os & 194 & 38 & 55 & 42 \\
167 os & 345 & 60 & 116 & 68 \\
168 os & 230 & 61 & 66 & 50 \\
169 os & 311 & 58 & 139 & 51 \\
17 os & 169 & 33 & 61 & 22 \\
171 os & 131 & 8 & 31 & 53 \\
172 os & 124 & 30 & 20 & 51 \\
173 os & 135 & 20 & 50 & 40 \\
174 os & 161 & 23 & 30 & 49 \\
175 os & 172 & 34 & 19 & 55 \\
176 os & 211 & 17 & 29 & 77 \\
177 OS & 208 & 25 & 51 & $6 \circ$ \\
178 os & 219 & 66 & 34 & 58 \\
179 os & 217 & 52 & 30 & 68 \\
\hline & & & & \\
\hline
\end{tabular}

23 Hannie van Goinga, 'Books on the Move: Public Book Auctions in the Dutch Republic, 1711-1805, Mainly in Amsterdam, Groningen, The Hague and Leiden', Quaerendo, 35 (2005), pp. 65-95, p. 91. 


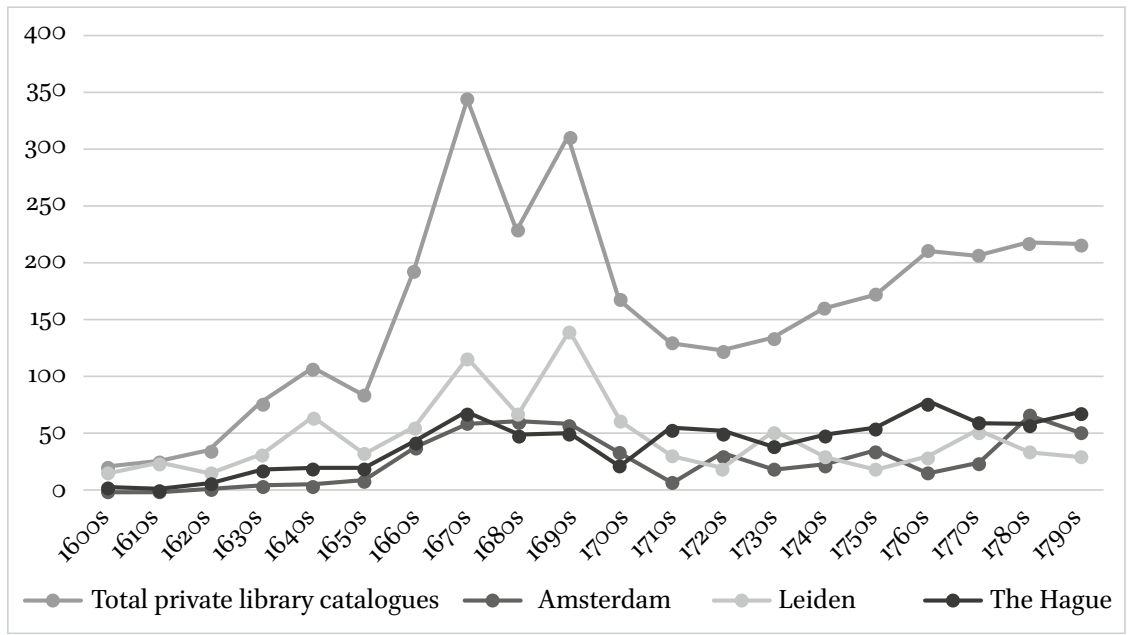

FIGURE 4.4 Private library catalogues sorted by city (16oos-179os) (absolute)

Leiden's leading position in the seventeenth century (when it comes to preserved catalogues) is ceded to The Hague in the eighteenth century (Figure 4.4). However, it is essential to realize that we are dealing here with preserved editions and not the number of auctions held.

We obtain a slightly more nuanced picture when we consider the importance of these three cities in relation to the total number of surviving auction catalogues (Figure 4.5). Once again it is clear that Leiden is the most important city when it comes to auctions, but that the city loses that position in the eighteenth century to The Hague. Amsterdam starts relatively late and remains relatively stable after the mid-seventeenth century - between $10 \%$ and $20 \%$ of the total (average over the period 1650-1799: 18.3\%).

With respect to other locations, the role of Utrecht (199 catalogues), Middelburg (121), and Rotterdam (109) is not inconsiderable. Table 4.4 provides an overview of places with ten or more preserved catalogues. ${ }^{24}$

24 Noteworthy is Batavia with nine catalogues. J. van Kan, De rechtsgeleerde boekenschat van Batavia ten tijde der Compagnie (Bandoeng: A.C. Nix and Co, 1935); Katharine Smith Diehl, Printers and Printing in the East Indies to 1850. Volume I Batavia (New Rochelle: Caratzas, 1990), pp. 170-183, 394-397, 424. 


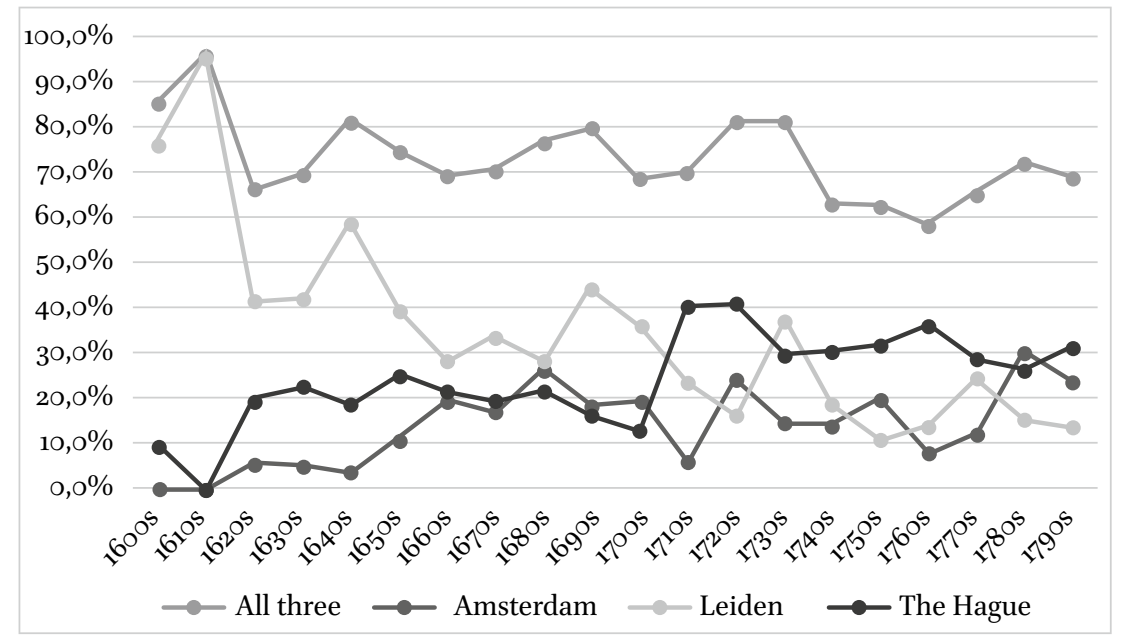

FIGURE 4.5 Private library catalogues for auctions in Amsterdam, Leiden, and The Hague relative to the total known number of auctions

TABLE 4.4 Private library catalogues sorted by number by city (16oos-179os)

\section{City}

\section{Count}

Leiden 914

The Hague

811

Amsterdam 544

Utrecht 199

Middelburg 121

Rotterdam 109

Groningen $\quad 77$

Den Bosch $\quad 67$

Leeuwarden $\quad 5^{\circ}$

Dordrecht 43

Haarlem 40

Delft 34

Franeker $\quad 26$

Maastricht 17

Deventer $\quad 15$

Arnhem 13

Nijmegen 12

Enkhuizen 10

Other 
Although this article focuses on private library catalogues, it is meaningful to provide context and therefore to draw a comparison with the origins of the other large group within book sales catalogue: the retail or wholesale stock catalogues (Figure 4.6):

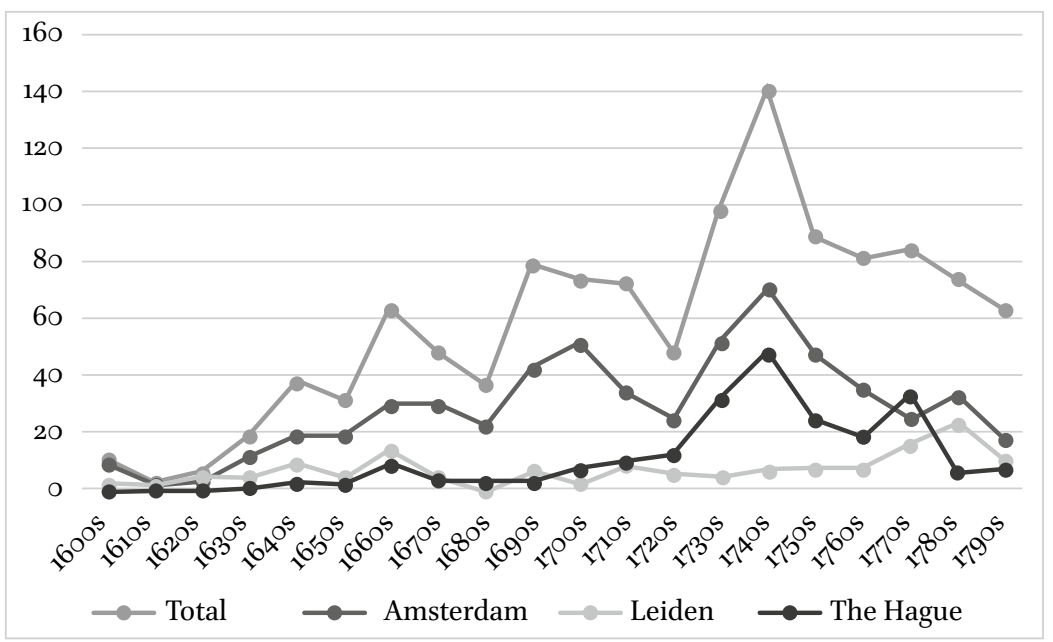

FIGURE 4.6 Retail or wholesale stock catalogues sorted by decade (16oos-179os) (absolute)

Compared with private library catalogues, it is striking that Leiden publishers produced fewer retail or wholesale stock catalogues, for which Amsterdam had the lead. More striking however, is the peak in the 1740s. This is related to an infamous crisis in the book trade in The Hague caused by the involvement of several booksellers in speculation on books and payments in bonds, resulting in a number of bankruptcies. ${ }^{25}$ It is interesting that during this decade not only in The Hague, but also in Amsterdam the number of preserved retail and wholesale stock catalogues increases. In Leiden however, the number of these catalogues hardly changes in the first half of the eighteenth century.

\section{Surviving Catalogues}

This data poses one further interpretative question. How representative is the sample of auctions known from surviving catalogues of the auction market as a

25 Hannie van Goinga, Alom te bekomen: veranderingen in de boekdistributie in de Republiek 1720-1800 (Amsterdam: De Buitenkant, 1999), pp. 133-135. 
whole? Van Goinga points out that the 'survival chances of catalogues are very erratic.' ${ }^{26}$ Catalogues often originate from collections of contemporary collectors, from bibliophiles eagerly looking for the latest catalogue in search of long cherished books or using them to create wish lists, to rich collectors who let their international agents visit the auctions and who received their purchased books together with the catalogues of the collections from which the books originated. Booksellers also regarded the catalogues annotated with the prices yielded as unique reference works and these too have been absorbed into institutional libraries in modern times. ${ }^{27}$ Earlier research has already shown that contemporary collectors mainly preserved the catalogues of the larger, more spectacular collections. ${ }^{28}$ This could mean that we have a distorted view of the book ownership since the catalogues of smaller collections are relatively absent. $^{29}$

This study is not the first attempt to estimate how many editions have been preserved and how many catalogues we consider as lost. In 1996, Gruys attempted to determine how many editions of catalogues have ever been printed. ${ }^{30} \mathrm{He}$ argued that, if Amsterdam, The Hague, Leiden, and the rest of the Dutch Republic, each had organised $25 \%$ of the auctions, we have $14 \%$ of the catalogues of the first three cities, and $6 \%$ of the last category. Overall, this meant that around $12 \%$ of the catalogues have be preserved. Reality, however, is different, and the preserved catalogues were not evenly distributed over the two centuries nor between the cities. Gruys concluded that from 1599 until 1800, 27,500 auctions had been organised. ${ }^{31}$ Since there were 3,300 editions of catalogues, this means 24,200 catalogues are lost. ${ }^{32}$

To gain a more complete picture of printed private library catalogues in the seventeenth and eighteenth century, it is important to realise what we have. How does a preserved catalogue of an auction relate to all those auctions for

26 Van Goinga, 'Books on the Move', p. 86.

27 Lankhorst, 'Vijftien pakketten'; Gruys, 'Rijklof Michael van Goens'; Keblusek, 'Gekocht in Den Haag'; Lankhorst, 'Les Ventes de Livres'.

28 Gruys, 'Rijklof Michael van Goens', p. 154; Lankhorst, 'Dutch Book Auctions', p. 68; Van Goinga, 'Books on the Move', p. 86.

29 Since book sale catalogues have only been drawn up for larger collections that were considered to hold a substantial value, probate inventories provide other information on historical book ownership, namely on smaller book collections.

30 Gruys, 'Rijklof Michael van Goens'.

31 At that time, the BSC database had 3,900 catalogues in 8,600 copies. By sampling 80 catalogues (every fiftieth issue), Gruys came to the conclusion that in $68.8 \%$ of the 3,900 catalogues only one preserved copy is known. Gruys, 'Rijklof Michael van Goens', pp. 152-154. Gruys, 'Rijklof Michael van Goens', pp. 154-155. 
which a catalogue has been printed, but of which we no longer have a copy? Van Goinga, Veldhuijzen, and Gerritsen posed the same question. They each tried to create a list of all auctions held in various Dutch cities in the eighteenth century based on archival material and newspaper advertisements. ${ }^{33}$ By comparing their numbers with BSC data, the percentage of preserved catalogues can be calculated. ${ }^{34}$ The catalogue was not only vital for marketing of sales, and in some cities, like Leiden and Amsterdam, it was mandatory to be able to present a catalogue to the authorities prior to the sale (eighteenth-century public book auctions were officially registered by the authorities or the booksellers' guild). ${ }^{35}$ We can therefore assume that for every auction held, there was a catalogue printed. Combining the data of Van Goinga, Veldhuijzen, and Gerritsen with the BsC data, a reliable estimation can be given of the chance of survival of Dutch printed private library sales catalogues in the eighteenth century. The available data covers the period $1711-1800 .{ }^{36}$

\section{The Number of Auctions}

When we look at the auctions held in the eighteenth century, we see that most auctions were organised in Amsterdam, Leiden, and The Hague. Amsterdam has the most with 3,099 auctions (32.9\%), followed by Leiden (1,970 auctions; $20.9 \%$ ), and The Hague (1,819 auctions; $19.3 \%$ ). Only $26.9 \%$ of all auctions took place in other Dutch cities. Utrecht follows with 521 auctions, together with Rotterdam (390), and Groningen (359). In all, 9,424 auctions took place in the Republic during these years.

33 Results published in Van Goinga, 'Books on the Move'. The combined data collections formed the core of the Repertorium van Nederlandse publieke boekenveilingen 1711-1805 which has been incorporated in Bibliopolis, the electronic national history of the printed book in the Netherlands: http://www.bibliopolis.nl.

34 Van Goinga, 'Books on the Move'. Particularly: Table 7, pp. 94-95.

35 At least in Leiden and Amsterdam, booksellers had to hand over a catalogue to the wardens of the guild for visitation to gain permission to organize the auction. Van Goinga, 'Books on the Move', pp. 70, 76; I.H. van Eeghen, De Amsterdamse boekhandel, 1680-1725, volume 5, part 1 (Amsterdam: N. Israel, 1978), pp. 237-274; Lankhorst, 'Les ventes de livres', p. 15 .

36 Cf. Van Goinga, 'Books on the Move', pp. 8o-88, 94-95 who carried out a similar study. She compared the amount of surviving catalogue and the number of auctions in Amsterdam, The Hague, Leiden, and Groningen. When comparing the data of Van Goinga, Veldhuijzen, and Gerritsen (in Van Goinga, 'Books on the Move') with the BSC data it is important to note that the coding is slightly different. The Bsc data was coded per decade, ranging from 1710 up to and including 1719 representing the 1710 . Van Goinga uses the range 1711 up to and including 1720 to represent the 1710s. Therefore, the comparisons over the decades of BSC catalogues and Van Goinga's auctions derives. 
Amsterdam may hold the leading position when it comes to auctions, but more catalogues have been preserved from The Hague and Leiden. Only 271 editions of the Amsterdam catalogues are known, a survival rate of $8.7 \%$. Compared to other cities in the Dutch Republic, this is one of the lowest percentages. Many smaller cities score better. It is striking that a city with such a high number of auctions, and associated book production, scores so low. A conclusive explanation for this is difficult to find.

For Leiden, the second city in terms of number of auctions, $14.9 \%$ of the catalogues have been preserved (294 editions). The Hague has a higher percentage of surviving editions, especially for a large city with many auctions: 511 editions, including a complete set of the auctions held in 1800 . This translates to $28.1 \%{ }^{37}$ The preservation of this complete collection of seventeen catalogues is due to two libraries, and its safeguarding is probably thanks to collector Johan Meerman. ${ }^{38}$ When we look at the number of inhabitants (estimate of around the year 1750), it is noticeable that although Amsterdam held many auctions, there were proportionately many more auctions per capita in The Hague and Leiden. ${ }^{39}$

Looking at the preserved catalogues for auctions held in the other cities in the Dutch Republic, the cities of Utrecht (16.7\%), Rotterdam (10.5\%), and Groningen (8.1\%) also have a low rate of survival. The situation is dramatically different in some of the smaller cities in the period 1711-180o. Den Bosch with 70 auctions and 59 known editions of catalogues, registers a survival rate of no less than $84.3 \%$. Maastricht (62.5\%), Vlissingen (30.8\%), and Harderwijk (30\%) also fare well, as did Delft (25.4\%), and Leeuwarden (26.6\%). Middelburg had around 164 auctions. Of these auctions, 96 catalogues (58.5\%) have been preserved. ${ }^{40}$

Table 4.5 shows the percentage of preserved catalogues per decade. ${ }^{41}$ Especially after the 176 os we have a larger percentage of surviving catalogues (Figure 4.7). In total, of a minimum of 9,424 auctions held in the period

37 The numbers are higher than Van Goinga, 'Books on the Move', p. 94. The percentages are: 7.9\%; Leiden 14.2\%; The Hague: $27.4 \%$; Groningen: [7.5\%].

38 Van Goinga, 'Books on the Move', p. 88. Eleven editions are in Museum Meermanno, five in the Royal Library, The Hague, and the last one in Paris.

39 A.M. van der Woude, 'De demografische ontwikkeling van de Noordelijke Nederlanden 1500-180o', in D.P. Blok (ed.), Algemene Geschiedenis Der Nederlanden 5. Nieuwe tijd: sociaal-economische geschiedenis, geografie en demografie 1500-1800, instellingen 14801780, politieke- en religiegeschiedenis na 1480 (Haarlem: Fibula-Van Dishoeck, 1980), pp. 102-168, pp. 136-139.

40 Only twelve of them are kept in the Zeeuwse Bibliotheek, Middelburg.

41 Based on the cities of we do have the numbers per decade (9,249): Amsterdam, Groningen, The Hague, Leiden, Arnhem, Den Bosch, Delft, Deventer, Dordrecht, Franeker, Gouda, Haarlem, Leeuwarden, Middelburg, Rotterdam, Utrecht, Zutphen and Zwolle. 
TABLE 4.5 The number of the auctions held, the number of preserved catalogues and percentage of preserved catalogues per decade

Years

\begin{tabular}{lrrr}
\hline $1711-1720$ & 708 & 127 & $17.9 \%$ \\
$1721-1730$ & 789 & 117 & $14.8 \%$ \\
$1731-1740$ & 1,075 & 130 & $12.1 \%$ \\
$1741-1750$ & 1,146 & 158 & $13.8 \%$ \\
$1751-1760$ & 1,157 & 167 & $14.4 \%$ \\
$1761-1770$ & 1,142 & 204 & $17.9 \%$ \\
$1771-1780$ & 1,172 & 198 & $16.9 \%$ \\
$1781-1790$ & $1,15^{2}$ & 208 & $18.1 \%$ \\
$1791-1800$ & 908 & 200 & $22.0 \%$ \\
Total & 9,249 & 1,509 & $16.3 \%$ \\
\hline
\end{tabular}

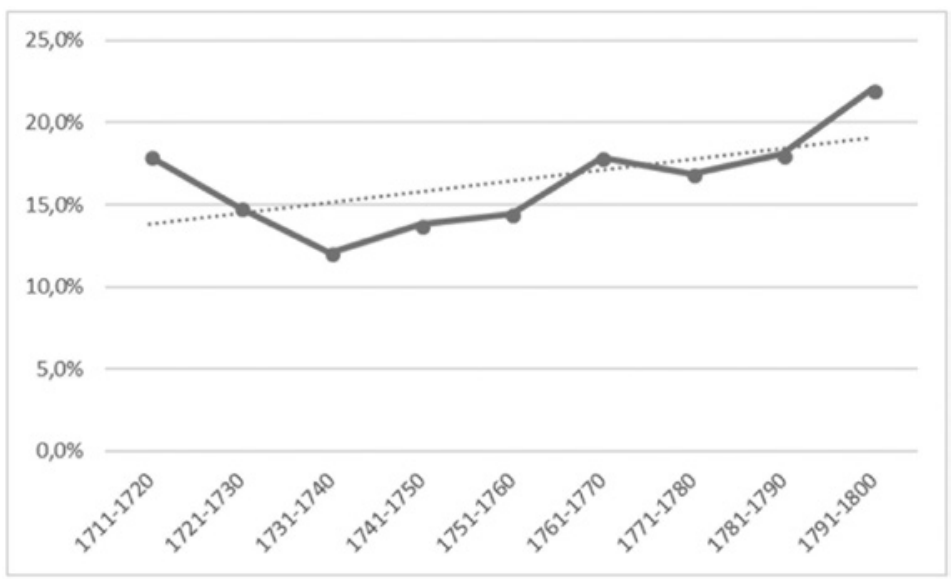

FIGURE 4.7 Percentage of preserved catalogues per decade

1711-180o, 1,539 catalogues have been preserved. This means in total $16.3 \%$ are preserved and that we do not have a copy of 7,885 editions of catalogues from the period 1711-180o.

For the second half of the seventeenth century, we can attempt a similar investigation for Leiden (Table 4.6). ${ }^{42}$

42 Based on: Van Goinga, 'Books on the Move', pp. 91-92; Laura Cruz, The Paradox of Prosperity: The Leiden Booksellers' Guild and the Distribution of Books in Early Modern Europe (New Castle, DE: Oak Knoll Press, 2009), p. 137. 
TABLE 4.6 Number of auctions held, the number of surviving editions of catalogues and the percentage of preserved editions of catalogues, in Leiden in the period 1650-1799

\begin{tabular}{|c|c|c|c|}
\hline Years & Auctions Leiden & Catalogues Leiden & Percentage \\
\hline 165 os & 297 & 33 & $11.1 \%$ \\
\hline 166os & 297 & 55 & $18.5 \%$ \\
\hline $1670 \mathrm{~s}$ & 221 & 116 & $52.5 \%$ \\
\hline 168os & 205 & 66 & $32.2 \%$ \\
\hline 169 os & 231 & 139 & $6 \circ .2 \%$ \\
\hline $1700 \mathrm{~s}$ & $25^{\circ}$ & 61 & $24.4 \%$ \\
\hline 171 os & 198 & 31 & $15 \cdot 7 \%$ \\
\hline $1720 s$ & 202 & 20 & $9 \cdot 9 \%$ \\
\hline 173 os & 273 & $5^{\circ}$ & $18.3 \%$ \\
\hline $1740 s$ & 295 & 30 & $10.2 \%$ \\
\hline $175^{\text {os }}$ & 205 & 19 & $9 \cdot 3 \%$ \\
\hline 176 os & 206 & 29 & $14.1 \%$ \\
\hline 177 os & 199 & $5^{1}$ & $25.6 \%$ \\
\hline 178 os & 198 & 34 & $17.2 \%$ \\
\hline 179 os & 194 & 30 & $15.5 \%$ \\
\hline
\end{tabular}

The data in Table 4.6 and Figure 4.8 show that relatively more catalogues from Leiden in the second half of this seventeenth century have been retained than from the eighteenth century. This raises the next question: is there a link between the production date of the catalogues and the survival rate? Since the complete data for auctions of the seventeenth century are missing, it is hard to give a conclusive answer to this question. However, we can calculate how many copies per edition have been preserved per decade in the period $1600-1799 .{ }^{43}$ Are more copies of a specific edition of catalogue retained from the seventeenth or from the eighteenth century?

As Table 4.7 shows, of 2,111 catalogues only one unique copy survives. This means they are among the rarest books in the world. Of 482 catalogues we still have two copies in of one the fifty European libraries surveyed for the BSC database. This number decreases quickly to 198 editions of which three copies are preserved. We still have four copies of 101 editions. Between eleven and twenty copies have been preserved of 74 editions of catalogues.

433,176 catalogues, in the period 1600-1799. Without 1599, catalogues after 1799, and 17uu. See note 21 . 


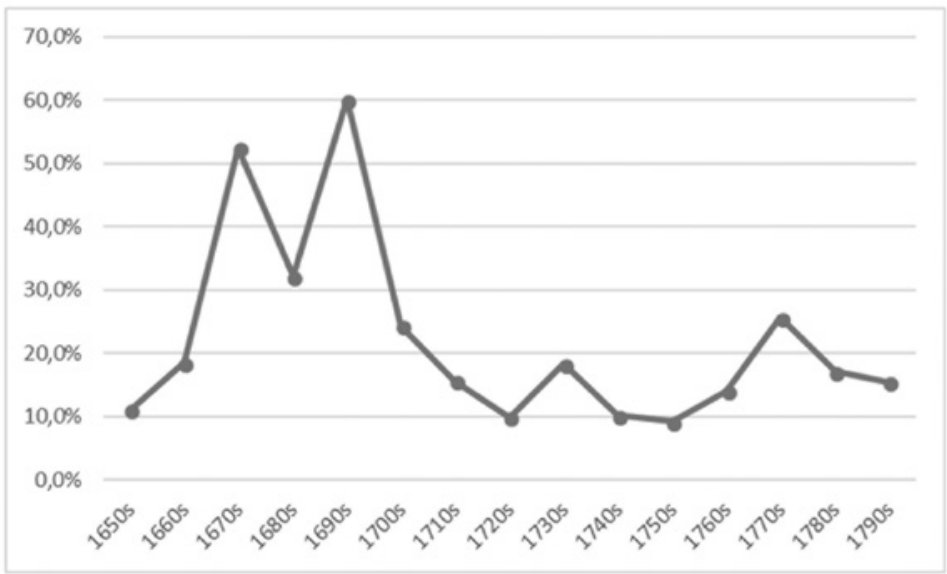

FIGURE 4.8 Percentage of preserved editions of catalogues, in Leiden in the period $165^{0-1799}$

TABLE 4.7 Number of editions and in how many copies they have been preserved

\begin{tabular}{|r|r|}
\hline Numbers of editions & Preserved copies \\
\hline 2,111 & 1 \\
\hline 482 & 2 \\
\hline 198 & 3 \\
\hline 101 & 4 \\
\hline 65 & 5 \\
\hline 30 & 6 \\
\hline 24 & 7 \\
\hline 12 & 8 \\
\hline 26 & 9 \\
\hline 9 & 10 \\
\hline 74 & $11-20$ \\
\hline 17 & $21-30$ \\
\hline 13 & $31-40$ \\
\hline 7 & $41-50$ \\
\hline 2 & $51-60$ \\
\hline 3 & $61-70$ \\
\hline 1 & $71-80$ \\
\hline 0 & $80-90$ \\
\hline 1 & $>90$ \\
\hline
\end{tabular}




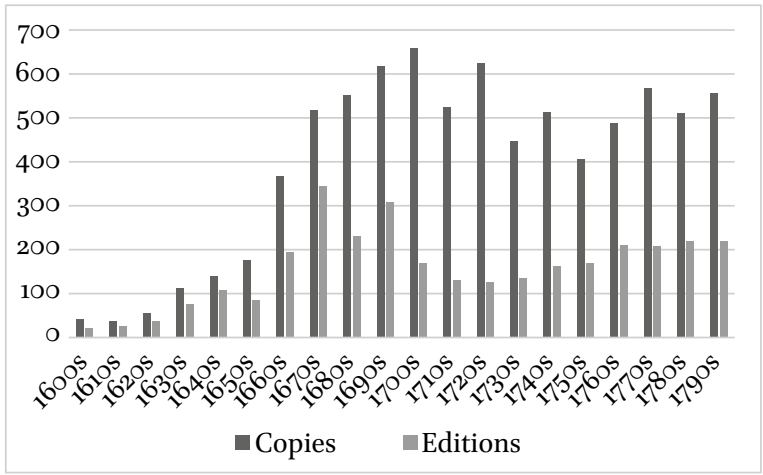

FIGURE 4.9 Number of preserved copies, compared with the number of surviving editions, sorted by decade

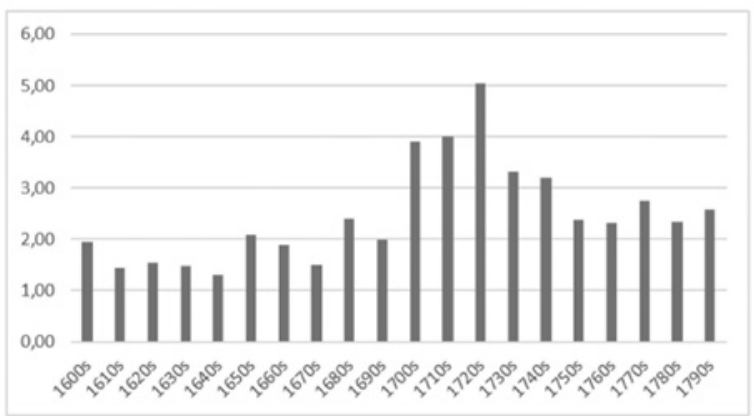

FIGURE 4.10 Ratio between the number of preserved copies and the editions, sorted by decade

With 92 copies, the Catalogue Des Livres De La Bibliothéque De M. Pierre-Antoine Bolongaro-Crevenna (1790) is the catalogue of which the most copies are preserved. ${ }^{44}$ The enormous collection of the wealthy merchant and bibliophile Bolongaro-Crevenna (1736-1792) was sold during his lifetime in Amsterdam. It is striking that this is a catalogue from the late eighteenth century. Is there a correlation between the more recent decades and the number of preserved specimens?

Figure 4.9 shows that from the second half of the seventeenth century onwards, more copies were preserved with each passing decade.

When we look at the ratio between the preserved editions and the number of preserved copies, Figure 4.10 shows that proportionally in the first half of the eighteenth century more copies have been saved. Noteworthy are the 1720 ,

44 Catalogue Des Livres De La Bibliothéque De M. Pierre-Antoine Bolongaro-Crevenna (Amsterdam: D.J. Changuion and P. den Hengst, 179o). 
in which for each edition there are on average five copies preserved. Looking at the numbers for each half century, we see that in terms of ratio, the second half of the eighteenth century scores the second best. Not surprisingly, the earliest fifty years (1600-1649) scores pro rata the lowest.

\section{Size of the Surviving Catalogues}

Private library catalogues come in all sizes. With only nine pages, the collection of Jacob Molenyser (a broker in The Hague) which was sold in 1732, contained 197 lots. ${ }^{45}$ This makes his collection one of the smaller auctioned collections. Other catalogues contain hundreds of pages. A preliminary study of 72 Dutch private library catalogues from $1670-175^{\circ}$, shows that the average is 33 items per page. However, this is an average and the real number depended on the design of the catalogue. ${ }^{46}$ Some catalogues carried 55 items per page, others hardly $18 .{ }^{47}$ In his study of the earliest of the Dutch book trade catalogues, Van Selm concluded that the size of the catalogues varied considerably from 16 to 120 pages. Three catalogues contain more than 2,000 items, ten between 1,000 and 2,00o, and fourteen fewer than 1,000.48

For the MEDiaTE project we look at Dutch, French, and English printed private library catalogues to study the circulation of books and ideas in eighteenth-century Europe. ${ }^{49}$ To research relatively modest libraries compared to large scholarly, encyclopaedic collections which sometimes contained thousands of titles - we examine catalogues of less than 1,ooo lots. With an estimated average of 20 lots per page, our intention is to look at catalogues of fewer than 53 pages. ${ }^{50}$ Several studies have suggested that these

45 As part of a larger auction; Catalogus variorum and insignium librorum (The Hague, 1732).

46 Some pages have a layout with two columns. Or they were printed in small format to be more convenient for letter post (Lankhorst, 'Dutch Book Auctions', p. 68).

47 Unpublished data collected for Alicia C. Montoya and Rindert Jagersma, 'Livres français dans les catalogues de vente aux enchères des bibliothèques privées dans les ProvincesUnies (1670-1750)' in Mathilde Bombart, etc. (eds.), "A qui lira": Littérature, livre et librairie en France au XVIIe siècle (Tübingen: Narr Francke Attempto Verlag, 2020), pp. 733-746. Of the 72 collections described, the average size is $1,044 \cdot 3$ items, remembering the notion that we only looked at catalogues with less than 53 pages.

48 Van Selm, Een menighte, p. 92.

49 A.C. Montoya, 'Middlebrow, religion, and the European Enlightenment. A new bibliometric project, MEDIATE (1665-1820)', French History and Civilization, 7 (2017), pp. 66-79, pp. 68-69.

$5^{\circ} \quad$ Alicia C. Montoya, 'Shifting Perspectives and Moving Targets: from Conceptual Vistas to Bits of Data in the First Year of the MEDIATE Project', in Simon Burrows and Glenn Roe 
smaller or medium-sized libraries are more likely to be 'choice libraries'. ${ }^{51}$ Owners of choice libraries are more expected to be real readers of the books they owned. By identifying and studying a corpus of collections of this size we hope to capture the real taste of the eighteenth-century book owners, instead of the libraries of collectors who aspired to gather all the knowledge of the world. ${ }^{52}$

What was the average size of the Dutch catalogue in the seventeenth and eighteenth century? To answer that question, we look at the number of catalogues with the name of one person on the title-page (single-person catalogues). After all, a catalogue comprised of two collections, distorts the image of the size of collections. ${ }^{53} \mathrm{~A}$ sample based on catalogues shows that in the last decades of the seventeenth century an average page contains 40 lots, while in the first half of the eighteenth century this numbers drops to 30 lots per page. In the seventeenth century, most catalogues were published in a quarto format. This switched suddenly to octavo in the 169os. In just two decades octavo had become the standard size. In the 168 os almost no catalogues were printed in octavo, in the 169 os, $13.4 \%$. In the 1700 , $47.6 \%$, almost half of them, are printed in octavo. A decade later, in the $1710 \mathrm{~s}, 86.7 \%$ of the catalogues appeared in octavo (leaving $13.3 \%$ in quarto). The seventeenth century is the age of the catalogue in quarto; the eighteenth century of the catalogue in octavo format.

The average size of the printed catalogues of the private library of one owner is 87 pages $(2,561$ lots $) \cdot{ }^{54}$ However, there are a lot of outliers. It is more fitting to look at the median, the middle score of the dataset. The median is $5^{2}$ pages; meaning that the lower $50 \%$ of the catalogues consist of $5^{2}$ or fewer pages, and the upper $50 \%$ consist of more than $5^{2}$ pages. This reveals that half of the Dutch printed private library catalogues of single person, are $5^{2}$ pages or less (first quartile $=28$ pages, third quartile $=104$ pages). Shown in Table 4.8, the most frequently occurring (mode) are catalogues with 32 pages (130), followed by those of 24 pages (122).

(eds.), Digitizing Enlightenment: Digital Humanities and the Transformation of EighteenthCentury Studies (Oxford: Oxford University Studies in the Enlightenment, 2020), pp. 195-218.

51 For an overview: Ibid.

$5^{2}$ Montoya and Jagersma, 'Livres français'.

53 Although of course a seemingly single-person catalogue (based on the name of the former owner on the title-page) can contain merged collections. Cf. Lankhorst, 'Dutch Book Auctions', pp. 72-75. An anonymous catalogue is counted as a single-person catalogue.

For some catalogues in the BSC database the number of pages is unknown. 
TABLE 4.8 Most common size of catalogues

\begin{tabular}{ll}
\hline Pages & Number of editions \\
\hline 32 & 130 \\
24 & 122 \\
16 & 112 \\
20 & 105 \\
40 & 98 \\
36 & 90 \\
44 & 81 \\
28 & 77 \\
48 & 74 \\
12 & 71 \\
56 & 67 \\
64 & 55 \\
8 & 54 \\
\hline
\end{tabular}

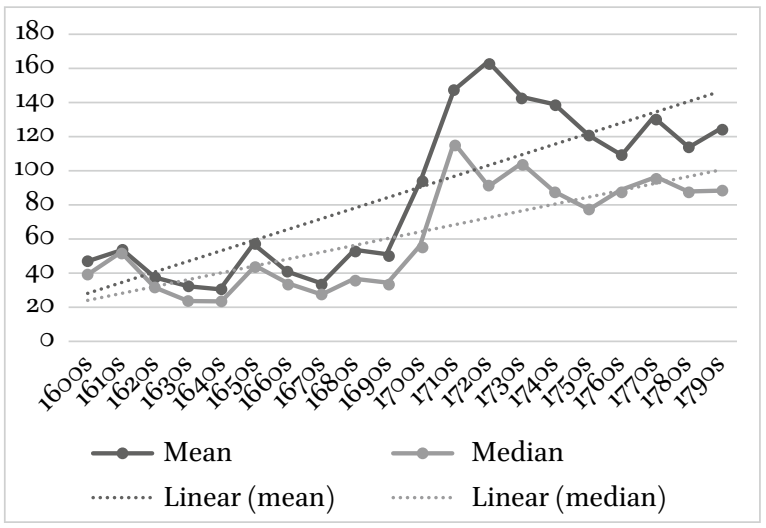

FIGURE 4.11 Mean and the median size of the catalogues throughout the decades, including trend line

Looking at the average size of the catalogue throughout the decades, we see a rise of larger catalogues after 1700. The upper line in Figure 4.11 indicates the average number of pages. However, due to the number of outliers, the median indicates a more moderate trend. Still, the sudden increase in size after 1700, and the peak of the 1710 , is surprising. The numbers suggest that personal libraries grow in size (Figure 4.12). One needs to keep in mind that the catalogues are (most often) drawn up after the collector's death, implicating that they reflect the purchases of an earlier period. 


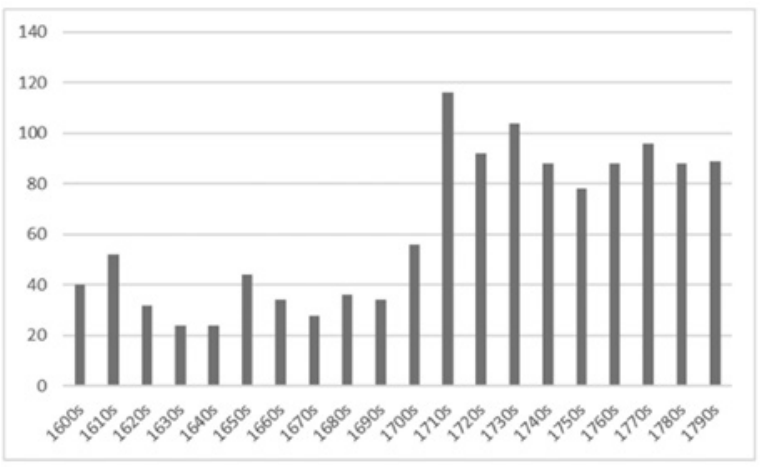

FIGURE 4.12 Median size of the catalogues, sorted by decade

Specifying the size of the catalogue by century, we see a clear growth of the collections that were offered for sale. The median size of catalogues in the seventeenth century is $3^{2}$ pages. For the eighteenth century this number more than doubles: 88 pages. When we look at catalogues with a median of more than $5^{2}$ pages (Table 4.9), we see that the collections grow up to and including the 165 os (88 pages for the 165 os). In the second half of the seventeenth century the median drops (64 pages in the 1670 s, 84 pages for the 1690 ). After this, an enormous growth follows (Figure 4.13). In the 1700 s the median length of the catalogues is 120 pages. This number continues to grow up to 134 pages in following decade (1710s). In the second half of the eighteenth century the median number of the pages of the larger catalogues increases, with the exception of the (1770s). In the last decade of the eighteenth century the median number of the pages of larger catalogues is 112 . When we look at the smaller collections (52 pages or fewer) we do see that, comparing the numbers between the seventeenth and eighteenth century, the median number of the catalogue pages does increase. Which means that also the smaller collections (although limited to 53 pages) do grow.

We can assume that there is a connection between the number of preserved copies and the size of the catalogues. ${ }^{55}$ Lankhorst once stated that the 'thicker the catalogue, the better the chance of survival; the more valuable a collection, the better chance that the catalogue was preserved by a collector.' ${ }^{56}$ This supposition is borne out by the evidence presented here. Of

\footnotetext{
55 Van Goinga, Alom te bekomen, p. 192.

56 Lankhorst, 'Dutch Book Auctions', p. 68. Cf. Van Goinga, 'Books on the Move', p. 86: 'a theory is held that thick catalogues for important collections have a better chance of survival than small specimens'.
} 
TABLE 4.9 Number of editions and the medians of catalogues of larger collections (more than $5^{2}$ pages), and the smaller collections (52 pages or fewer) throughout the decades

\begin{tabular}{|c|c|c|c|c|}
\hline Year & $\begin{array}{l}\text { Count Editions } \\
\leq 5^{2}\end{array}$ & Median $\leq 5^{2}$ & $\begin{array}{l}\text { Count Editions } \\
>5^{2}\end{array}$ & Median $>5^{2}$ \\
\hline 1600 s & 14 & 36 & 6 & 72 \\
\hline 161 os & 11 & 36 & 8 & 73 \\
\hline $1620 \mathrm{~s}$ & 21 & 30 & 4 & 78 \\
\hline 163 os & 59 & 20 & 12 & 80 \\
\hline $1640 \mathrm{~S}$ & 78 & 24 & 9 & 82 \\
\hline 165 os & 39 & 36 & 24 & 88 \\
\hline 166 os & 127 & 32 & 42 & 73 \\
\hline $1670 \mathrm{~s}$ & 262 & 24 & 47 & 64 \\
\hline 168 os & 156 & $3^{\circ}$ & 44 & 74 \\
\hline 169 os & 198 & 28 & 65 & 84 \\
\hline 1700 s & 70 & $3^{2}$ & 73 & 120 \\
\hline 1710 s & 22 & 35 & 81 & 134 \\
\hline $1720 \mathrm{~s}$ & 23 & 36 & 76 & 121 \\
\hline 173 os & 27 & 30 & 77 & 122 \\
\hline $1740 \mathrm{OS}$ & 32 & 36 & 95 & 126 \\
\hline 175 os & 40 & 37 & 89 & 118 \\
\hline $1760 \mathrm{~s}$ & 34 & 39 & 113 & 116 \\
\hline $177 \mathrm{Os}$ & 34 & 36 & 125 & 122 \\
\hline 178 os & 41 & 44 & 119 & 116 \\
\hline 179 os & 34 & 37 & 130 & 112 \\
\hline
\end{tabular}

the 34 auctions with proceeds of more than $f$ 10,ooo (organised in Leiden, The Hague and Groningen), a catalogue is preserved in every case. This contrasts with the mere $9 \%$ of surviving catalogues of which the auctions had proceeds of between $f 500$ and $f$ 1,0oo. Of catalogues of auctions with proceeds between $f_{2} 200$ and $f_{500}$, only $5 \%$ are preserved. Copies of half of the catalogues of auctions that raised $f_{3}, 000-f_{5}, 000$ can be traced. ${ }^{57}$ This leads to the conclusion that there is a clear connection between and the value of the collection and the number of surviving catalogues. Is there also a connection between the 


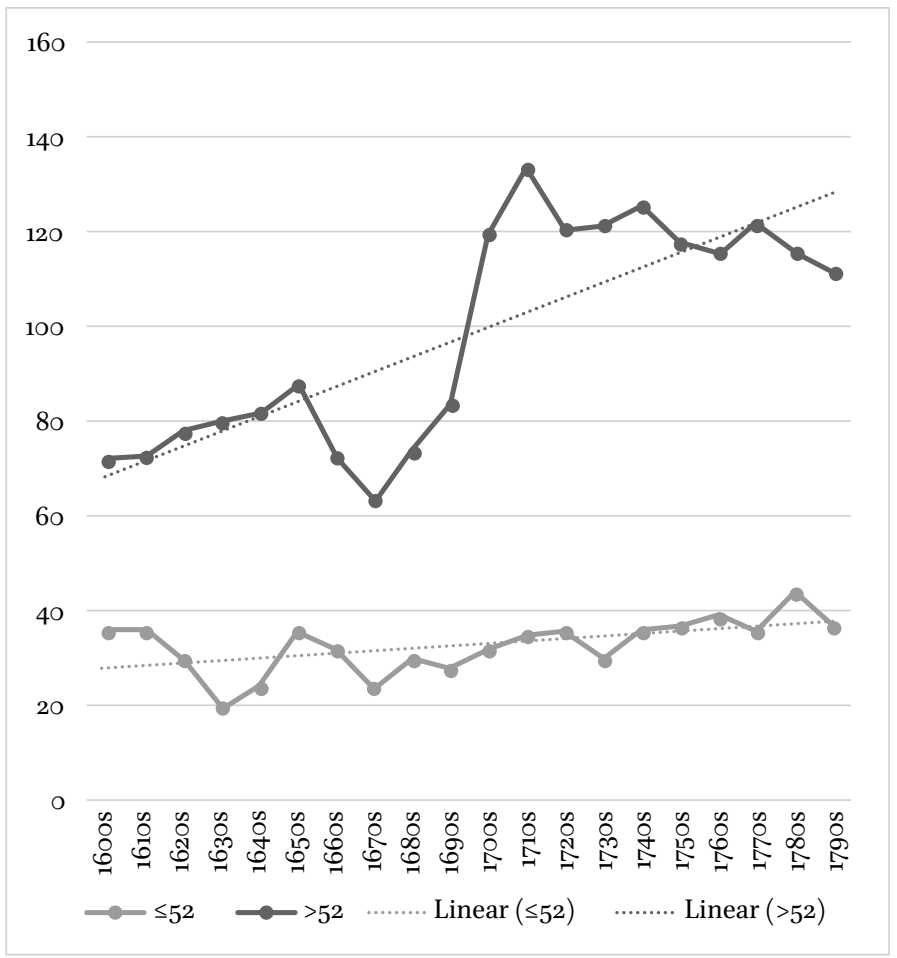

FIGURE 4.13 Medians of catalogues of larger collections (more than $5^{2}$ pages), and the smaller collections ( $5^{2}$ pages or fewer) throughout the decades, including trend line

size of the catalogues and the number of preserved copies? To establish this, we split the catalogues again in smaller ( $5^{2}$ pages or fewer) and larger collections (more than $5^{2}$ pages).

As Table 4.10 shows, over $80 \%$ of the catalogues of smaller collections have survived in a unique copy $(1,065)$. Two or more copies are known in only $20 \%$ of cases (257). From the larger collections however, it is more equally divided: $47,9 \%$ are unique (593), compared to $52.1 \%$ (646) of which more than one copy is known. In total, almost two-third $(64.7 \%)$ of the catalogues $(1,658)$ are unique. ${ }^{58}$ It can be concluded that larger catalogues (more than $5^{2}$ pages) are handed down in larger numbers than the small ones ( $5^{2}$ pages or fewer).

$5^{8}$ Concerning catalogues with collections of multiple persons (348), there are 75 editions with $\leq 5^{2}$ pages and 273 editions with $>5^{2}$ pages. Not surprisingly, multi-person catalogues are often more extensive. 
TABLE 4.10 Number of preserved copies sorted by smaller ( $5^{2}$ pages or fewer) and larger collections (more than $5^{2}$ pages)

\begin{tabular}{|c|c|c|c|c|c|}
\hline & & & \multicolumn{2}{|c|}{ Preserved copies } & \multirow[t]{2}{*}{ Total } \\
\hline & & & 1 copy & $>1$ copy & \\
\hline \multirow{3}{*}{ Pages } & $\leq 5^{2}$ & Count & 1,065 & 257 & 1,322 \\
\hline & & Percentage & 8 о. $6 \%$ & $19.4 \%$ & $100.0 \%$ \\
\hline & $>5^{2}$ & Count & 593 & 646 & 1,239 \\
\hline \multirow{3}{*}{ Total } & & Percentage & $47.9 \%$ & $52.1 \%$ & $100.0 \%$ \\
\hline & & Count & $1,65^{8}$ & $9 \circ 3$ & 2,561 \\
\hline & & Percentage & $64.7 \%$ & $35 \cdot 3 \%$ & $100.0 \%$ \\
\hline
\end{tabular}

TABLE 4.11 Smaller ( $5^{2}$ pages or fewer) and larger collections (more than $5^{2}$ pages) sorted by location

\section{Pages Total}

$\leq 5^{2} \quad>5^{2}$

\begin{tabular}{|c|c|c|c|c|c|}
\hline & Other & Count & 382 & 386 & 768 \\
\hline \multirow{5}{*}{ Location } & & Percentage & $49 \cdot 7 \%$ & $50.3 \%$ & $100.0 \%$ \\
\hline & Amsterdam & Count & 279 & 208 & 487 \\
\hline & & Percentage & $57 \cdot 3 \%$ & $42.7 \%$ & $100.0 \%$ \\
\hline & The Hague & Count & 233 & 355 & 588 \\
\hline & & Percentage & $39.6 \%$ & $60.4 \%$ & $100.0 \%$ \\
\hline \multirow{4}{*}{ Total } & Leiden & Count & 428 & 290 & 718 \\
\hline & & Percentage & $59.6 \%$ & $40.4 \%$ & $100.0 \%$ \\
\hline & & Count & 1,322 & 1,239 & 2,561 \\
\hline & & Percentage & $51.6 \%$ & $48.4 \%$ & $100.0 \%$ \\
\hline
\end{tabular}

When looking at the size of the catalogue, we can wonder if there is a link between the location and the size of the collection auctioned. Table 4.11 shows an interesting pattern. In both Amsterdam and Leiden, about $6 \circ \%$ of the catalogues contain $5^{2}$ pages or fewer $(57.7 \%$ and $59.6 \%$ respectively). For The Hague these numbers are reversed. In the case of The Hague, $60.4 \%$ (355) of the catalogues are larger than $5^{2}$ pages. The remaining $30 \%$ of the catalogues, 
derived from other locations, are evenly distributed $\left(49.7 \% 5^{2}\right.$ pages or fewer, versus $50.3 \%>5^{2}$ pages).

Another relationship worth exploring is that between the age of the collector and the size of the catalogue. The assumption is that older people have larger collections of books. After all, they have had more time to put together a collection. It is possible to establish the age of 690 collectors when they passed away (Table 4.12). ${ }^{59}$

TABLE 4.12 Smaller (52 pages fewer than) and larger collections (more than $5^{2}$ pages) sorted by age

\begin{tabular}{|c|c|c|c|c|c|}
\hline & & \multicolumn{3}{|c|}{ Pages } & \multirow[t]{2}{*}{ Total } \\
\hline & & & $\leq 5^{2}$ & $>5^{2}$ & \\
\hline \multirow{14}{*}{$\begin{array}{l}\text { Age } \\
\text { (years) }\end{array}$} & $20-29$ & Count & 4 & 5 & 9 \\
\hline & & Percentage & $44.4 \%$ & $55.6 \%$ & $100.0 \%$ \\
\hline & $3^{0}-39$ & Count & 30 & 15 & 45 \\
\hline & & Percentage & $66.7 \%$ & $33 \cdot 3 \%$ & $100.0 \%$ \\
\hline & $40-49$ & Count & 47 & 54 & 101 \\
\hline & & Percentage & $46.5 \%$ & $53.5 \%$ & $100.0 \%$ \\
\hline & $5^{\circ-59}$ & Count & 69 & 90 & 159 \\
\hline & & Percentage & $43.4 \%$ & $56.6 \%$ & $100.0 \%$ \\
\hline & $6 o-69$ & Count & 65 & 116 & 181 \\
\hline & & Percentage & $35 \cdot 9 \%$ & $64.1 \%$ & $100.0 \%$ \\
\hline & $70-79$ & Count & 30 & 112 & 142 \\
\hline & & Percentage & $21.1 \%$ & $78.9 \%$ & $100.0 \%$ \\
\hline & $8 o-89$ & Count & 11 & 37 & 48 \\
\hline & & Percentage & $22.9 \%$ & $77.1 \%$ & $100.0 \%$ \\
\hline \multirow{4}{*}{ Total } & $90-99$ & Count & o & 5 & 5 \\
\hline & & Percentage & ०,०\% & $100.0 \%$ & $100.0 \%$ \\
\hline & & Count & $25^{6}$ & 434 & 690 \\
\hline & & Percentage & $37.1 \%$ & $62.9 \%$ & $100.0 \%$ \\
\hline
\end{tabular}

59 Catalogues with the name of one collector (single-person catalogues), according to the title-page, and if the owner was more than 20 years old. 


\section{The Age of the Collectors}

Figures 4.14-15 and Table 4.13 show that we have few catalogues of young collectors (who died in their twenties). Of people in their thirties, often a smaller collection (52 pages or fewer) was auctioned, compared to collectors who died at a later age. The difference starts to grow among the collectors who died somewhere between their 4oth and 5oth year. In this category the number of books in the collection increases.

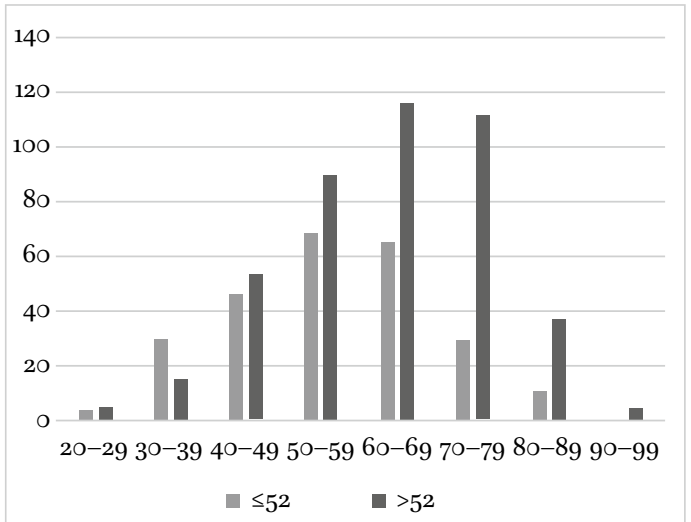

FIGURE 4.14 Smaller (52 pages or fewer) and larger collections (more than $5^{2}$ pages) sorted by age (absolute)

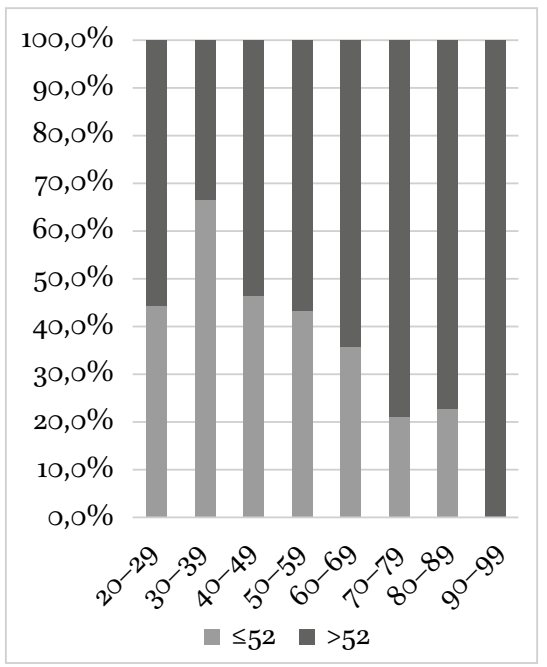

FIGURE 4.15

Smaller ( 52 pages or fewer) and larger collections (more than $5^{2}$ pages) sorted by age (relative) 
TABLE 4.13 Smaller ( 52 pages or fewer) and larger collections (more than $5^{2}$ pages) sorted by age (under 6o or 6o and over)

\begin{tabular}{|c|c|c|c|c|c|}
\hline & & \multicolumn{3}{|c|}{ Pages } & \multirow[t]{2}{*}{ Total } \\
\hline & & & $\leq 5^{2}$ & $>5^{2}$ & \\
\hline & $<6 \circ$ & Count & $15^{\circ}$ & 164 & 314 \\
\hline & & Percentage & $47.8 \%$ & $52.2 \%$ & $100.0 \%$ \\
\hline \multirow[t]{2}{*}{ Age } & $>60$ & Count & 106 & 270 & 376 \\
\hline & & Percentage & $28.2 \%$ & $71.8 \%$ & $100.0 \%$ \\
\hline \multirow[t]{2}{*}{ Total } & & Count & 256 & 434 & 690 \\
\hline & & Percentage & $37.1 \%$ & $62.9 \%$ & $100.0 \%$ \\
\hline
\end{tabular}

\section{Auction Season}

When was the best time to hold an auction? When we look at which months the auctions were held, based on preserved catalogue, we see something remarkable that was already suspected by Van Selm. ${ }^{60}$ Based on the auction dates of the first decade of the seventeenth century, he showed that most auctions took place in the late spring/early summer and autumn. This was probably due to better weather circumstances in these months, in which it was more comfortable to travel. Similar, the non-winter seasons were more convenient for transport, fairs and mail delivery. ${ }^{61}$

Analysing all the dates on which the auctions were held $(3,086)$, it is evident that we can speak of 'auction seasons' (Figure 4.16). Spring (March, April, May), and autumn (September, October, November) are the seasons in which most auctions took place. The decline in the summer months could have to do with recess and people leaving the city.

When we look at the percentage of catalogues with $5^{2}$ pages or fewer (smaller collections), and more than $5^{2}$ pages (the 'larger' collections), we see that in relative terms the months of April, June, September, October and November were the optimum time to bring books to market (Figure 4.17). In the month of July, only $38.2 \%$ of the catalogues contained over $5^{2}$ pages, meaning that $61.8 \%$ of the auctioned collections can be considered as 'smaller'. But

6o Van Selm, Een menighte, p. 8 o.

61 Ibid. 


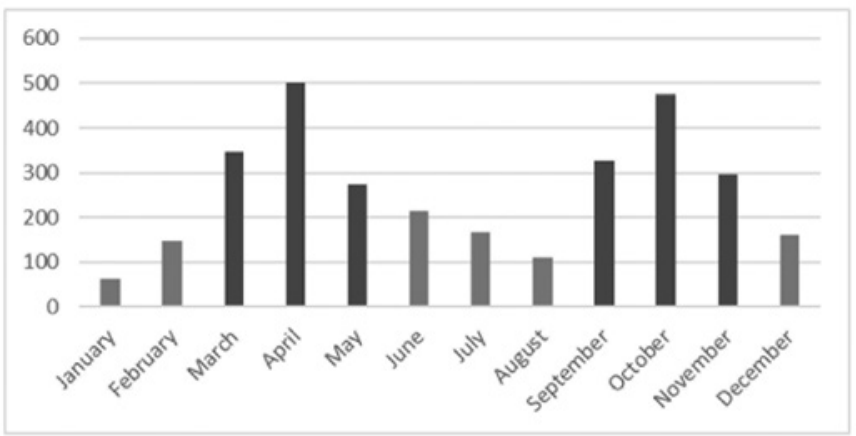

FIGURE 4.16 Number of catalogues sorted by the month when the auction was held

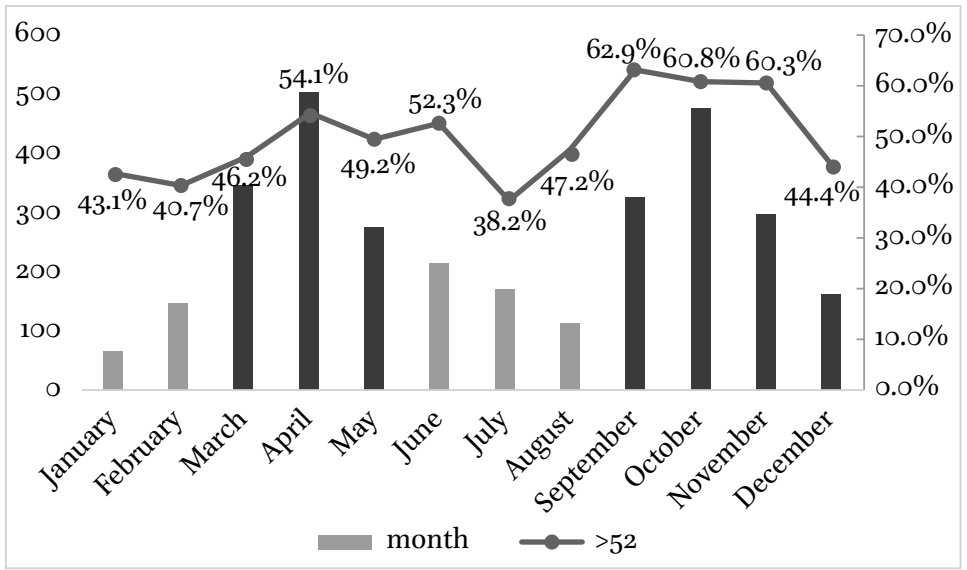

FIGURE 4.17 Number of catalogues sorted by the month when the auction was held, compared with the percentage of the catalogues that had more than $5^{2}$ pages (the larger collections)

certainly, for autumn it is explicit that larger collections are auctioned, with over $60 \%$ of the catalogues of containing more than $5^{2}$ pages.

\section{Conclusion}

This study attempts to gain a more complete picture of Dutch printed private library sale catalogues in the seventeenth and eighteenth century, by describing what we know about the catalogues based on the most complete data available. Building on foundations of the project 'Book Sales Catalogues of the 
Dutch Republic, 1599-180o', by Bert van Selm, we can gain a more complete view of what was published and create a typology of the preserved Dutch book sales catalogues.

Compared to the seventeenth century, the number of private library catalogues do increase in the eighteenth century, although we also have many catalogues from the period 166o-1699. Comparing the number of preserved catalogues and organised auctions in the eighteenth century, we see that the years $1720-1759$ score below the average. Striking is that this is the period from which proportionally more copies of the editions have been saved. Most editions are preserved in only one copy. Leiden has the most preserved catalogues for the seventeenth century, but loses that position in the eighteenth century to The Hague. Local regulations of the city and the guild should also be taken in consideration. Relatively few catalogues from Amsterdam are preserved. For the eighteenth century the survival rate of printed private library catalogues is $16.3 \%$. Considering a print run of hundreds of copies per edition, the amount of lost printed matter is enormous.

The assumption that the thicker the catalogue, the higher the chance of survival, proves to be correct. The median of a seventeenth-century catalogue is 32 pages, while this number more than doubles (88 pages) in the eighteenth century. Over time, the larger collections (more than $5^{2}$ pages) become larger, and the smaller catalogues ( 52 pages or fewer) also grow. Owners who lived longer had larger libraries. We can speak of auction seasons in spring (March, April, May), and autumn (September, October, November). Around these months, the larger collections were auctioned. 